\title{
Belajar Asyik Masa Pandemi: Inovasi Belajar Pidato Melalui Media Pembelajaran Kreatif
}

\author{
Sari Oktafiani* \\ E-mail: sarioktafiani39@gmail.com \\ Program Studi Pendidikan Bahasa dan Sastra Indonesia, Universitas Riau
}

\section{Pengantar}

Munculnya virus corona (Covid-19) di Indonesia mengharuskan seluruh kegiatan manusia dilakukan dari rumah, termasuk dalam proses pembelajaran. Hal ini berguna untuk memutus mata rantai penyebaran virus corona di Indonesia, sehingga tidak memicu angka penularan yang tinggi dan nantinya berisiko untuk kesehatan. Kegiatan yang biasanya dilakukan secara langsung, tetapi harus dialihkan secara daring mengharuskan kita untuk dapat beradaptasi dengan keadaan yang dirasakan. Berbagai inovasi-inovasi muncul sebagai media pendukung proses kegiatan manusia.

Menghadapi kondisi seperti ini, pendidik harus memiliki berbagai cara agar kegiatan belajar mengajar masih tetap bisa dilaksanakan, sehingga peserta didik dapat terpenuhi kebutuhannya, dan guru dapat menjalankan kewajibannya. Maka, pendidik haruslah mengikuti perkembangan teknologi dan mau belajar sehingga dapat menerapkan teknologi yang muncul demi mendukung pembelajaran, khususnya pada masa pembelajaran daring. Media pembelajaran adalah sebuah alat yang berfungsi untuk menyampaikan pesan pembelajaran serta sebuah proses komunikasi antara pembelajar, pengajar dan bahan ajar. Komunikasi tidak akan berjalan tanpa bantuan sarana penyampai pesan atau media (Faizah, Charlina, Arini \& Zulhafizh, 2015:33). Beberapa media pembelajaran kreatif yang merupakan hasil dari inovasi dan dapat digunakan diantaranya adalah google classroom, google meet dan zoom. Tidak hanya itu, media sosial juga dapat digunakan sebagai sarana pembelajaran seperti WhatsApp dan Telegram. Kemudian beberapa aplikasi seperti Youtube, Google Drive, atau situs-situs pembelajaran yang terdapat di internet. Apapun keadaannya, aktivitas belajar seseorang tidak harus berkurang secara 
kualitas maupun kuantitas. Hal ini perlu penyesuaian satu dengan yang lainnya (Zulhafizh \& Permatasari, 2020:938). Hasil penelitian Ayu (2020) menunujukkan bahwa peserta didik yang menggunakan e-learning atau pembelajaran daring dalam proses belajar lebih bersemangat dan merasakan kemudahan dalam mengakses serta memahami materi daripada peserta didik konvensional karena materi yang disampaikan secara daring lebih menarik dan dapat diakses setiap saat (Ayu,dkk, 2021:51).

Pidato merupakan salah satu materi pembelajaran yang dapat kita temukan pada kelas XI jenjang Sekolah Menangah Pertama (SMP) pada KD 3.4 dan 4.4. Menurut Tarigan (dalam Huriah, 2021:6488) Pidato atau Presentasi merupakan suatu keterampilan berbahasa yang dipergunakan untuk berkomunikasi secara tidak langsung, tidak secara tatap muka dengan orang lain. Pidato merupakan salah satu keterampilan berbahasa yang mengajarkan kita bagaimana berbicara di depan umum. Keterampilan berpidato akan lebih efektif apabila diajarkan secara langsung, karena keterampilan ini membutuhkan praktik berulang agar dapat berpidato dengan baik. Pada masa pandemi, materi pidato harus beradaptasi dengan kondisi PJJ (Pembelajaran Jarak Jauh) sehingga materi pidato ini harus diajarkan dengan cara menarik sehingga dapat meningkatkan minat belajar peserta didik. Seorang guru bertanggung jawab atas keberhasilan peserta didiknya dalam mempelajari keduanya secara teoritis dan praktis (Mustafa, Hermandra \& Zulhafizh, 2019:14). Sehingga, pendidik harus dapat menemukan strategi untuk melakukan pembelajaran dengan menyenangkan.

\section{Tindakan yang Dilakukan}

Guru sebagai pendidik dituntut untuk mampu beradptasi dan menciptakan suasana belajar yang menarik saat melakukan pembelajaran secara daring. Agar materi yang diajarkan dapat terlaksana dan mencapai tujuannya. Ada beberapa cara yang dapat dilakukan untuk melaksanakan pembelajaran secara asyik, dan menyenangkan melalui media pembelajaran kreatif, diantaranya: 


\section{Menciptakan permainan untuk penyampaian materi.}

Permainan ini dapat dibuat oleh guru meggunakan spin, atau roda putar yang sekarang sudah tersedia secara daring sehingga memudahkan untuk digunakan tanpa harus mengunduh aplikasi terlebih dahulu. Nantinya, peserta didik akan dibagi menjadi beberapa kelompok untuk selanjutnya ditentukan akan menampilkan materi yang didapatkan dari pemutaran roda tersebut. Permainan ini dapat dimodifikasi sesuai dengan ide yang timbul dari pendidik maupun peserta didik. Hal ini nantinya akan membuat pembagian materi secara adil dan pembelajaran jadi lebih menyenangkan karena kita dibuat penasaran terlebih dahulu sampai keluar hasilnya.

\section{Memberikan contoh video berpidato yang dapat diakses peserta didik} kapan saja.

Setelah teori dikuasai oleh peserta didik, langkah selanjutnya adalah penerapannya dengan melakukan praktik. Sebelum peserta didik melakukan praktik, guru haruslah terlebih dahulu menampilkan sebuah video tentang pidato dan contohnya terlebih dahulu. Video ini dapat ditemukan di platform Youtube atau beberapa media sosial seperti Instagram ataupun Facebook yang memungkinkan pengguna untuk membagikan kegiatan berupa video. Video hendaklah dibuat semenarik mungkin mulai dari pembukannya sampai penutup, agar saat menonton peserta didik tidak merasa bosan. Alangkah lebih baik lagi apabila yang mempraktikkannya dalam video tersebut adalah guru yang mengajarkannya.

\section{Memberikan tugas berpidato, kemudian diunggah di Youtube.}

Setelah peserta didik melihat video praktik berpidato, maka selanjutnya guru memberikan tugas berupa pembuatan video berpidato yang akan dilakukan oleh masing-masing peserta didik dan nantinya akan diunggah di Kanal Youtube. Untuk kanal Youtube, peserta didik akan diberi pilihan oleh guru, akan menggunakan kanal Youtube pribadi atau membuat 
kanal Youtube kelas yang dapat digunakan oleh seluruh peserta didik di kelas tersebut.

\section{Memberikan penghargaan kepada peserta didik.}

Setelah peserta didik menyelesaikan tugasnya, guru hendaklah memberikan reward atau penghargaan kepada peserta didik. Tidak harus berupa materil, melainkan berupa pujian saja sudah sangat baik untuk meningkatkan kepercayaan diri peserta didik dan membuat ia lebih nyaman menerima pelajaran yang diajarkan kepadanya.

\section{Mengulas kembali pelajaran melalui tes quizizz.}

Setelah selesai penyampaian teori dan praktik, maka kita dapat memastikan tingkat pemahaman peserta didik melalui sebuah tes. Tes yang biasa digunakan bisa melalui google formulir. Tetapi, untuk membuat pelajaran lebih menyenangkan, guru dapat menggunakan sebuah aplikasi Bernama Quizizz. Sehingga tes rasanya seperti bermain dan dapat meningkatkan antusias peserta didik dalam menghadapi sebuat tes. Karena biasanya, peserta didik akan takut atau tidak siap dalam menghadapi tes, seperti ujian. Lewat aplikasi ini, peserta didik diharapkan dapat mengerjakan tes dengan perasaan yang senang.

\section{Sarana Pendukung}

\section{Google Classroom}

Google Classroom adalah aplikasi buatan google. Google classroom merupakan aplikasi yang dapat menciptakan kelas secara daring sehingga dapat mempermudah penyampaian materi, pembagian dan pengumpulan tugas, dan dapat pula melakukan penilaian terhadap tugas-tugas yang telah dikumpulkan oleh peserta didik sehingga peserta didik dapat mengetahui hasil dari pekerjaannya. Google Classroom memiliki fitur untuk mengunggah video atau menautkan tautan video dari YouTube maupun dari Google Drive, terdapat pula forum diskusi sehingga dosen bisa membuka sebuah diskusi kelas dan dapat 
ditanggapi oleh seluruh peserta didik yang tergabung pada ruang kelas tersebut. Aplikasi ini lebih mudah digunakan untuk menghimpun tugas kelas dibandingkan pengumpulan tugas melalui email. Tugas yang dikumpulkan melalui email tidak tersusun menjadi tiap folder mata pelajaran. Sehingga kegiatan pengumpulan tugas menjadi terhambat (Rahma dan Arista, 2020:89).

Guru dapat menautkan materi pidato ataupun video yang berkaitan untuk dapat dilihat oleh siswa yang berada pada ruang kelas google tersebut.

\section{Google Meet dan Zoom}

Google meet dan Zoom merupakan aplikasi konferensi video yang dapat memungkinkan pengguna melakukan obrolan atau interaksi dengan banyak orang. Pengguna dapat membuat ruang obrolan dengan mudah, setelah ruang obrolan terbuat akan muncul kode atau tautan yang dapat dibagi pada pengguna lainnya. Pada aplikasi google meet, jumlah partisipan dibatasi hanya sampai 100 orang tetapi tidak dibatasi oleh waktu. Berbeda dengan Zoom, Zoom mempunyai fitur dasar yaitu partisipan bisa sampai seratus orang dengan waktu meeting empat puluh menit yang bisa didapatkan secara gratis, untuk menikmati fitur yang lebih banyak bisa berlangganan dengan zoom business (Aditia, 2021:18). Pada aplikasi ini, terdapat pula fitur papan tulis. Aplikasi ini juga memungkinkan pengguna untuk berbagi layar, sehingga memudahkan presentasi saat menerangkan materi pelajaran. Pada ruang obrolan google meet dan zoom, terdapat fitur pesan yang dapat digunakan pengguna untuk mengetik pesan yang akan disampaikan, hal ini menjadi alternatif apabila terdapat gangguan pada suara perangkat. Disediakan pula fitur angkat tangan atau raise hand yang memudahkan guru melihat peserta didik yang ingin berbicara.

Aplikasi ini memudahkan guru untuk menerangkan pelajaran, dalam hal ini adalah materi pidato, sehingga tetap terasa seperti di dalam kelas saat sebelum pembelajaran daring. Penerangan materi pembelajaran juga dapat dimaksimalkan dengan menggunakan aplikasi ini. 


\section{Youtube}

Youtube merupakan platform yang sudah sangat populer di kalangan masyarakat. Youtube berisi berbagai video, termasuk di dalamnya video pembelajaran yang dapat menunjang proses belajar mengajar serta meningkatkan kemampuan dalam memahami materi. YouTube sebagai sebuah platform memungkinkan pengguna untuk mencari, mengunggah, berdiskusi melalui fitur yang tersedia, dan seluruh fitur pada Youtube tidak dikenakan bayaran. Youtube dapat diakses dengan sambungan internet. Tetapi, ada alternatif lain yang dapat dilakukan apabila ingin menonton video yang sama tanpa harus terhubung ke internet. Caranya adalah pengguna harus mengunduh video tersebut terlebih dahulu melalui fitur yang telah disediakan, setelah unduhan selesai video dapat dinikmati kapan saja tanpa harus terhubung ke internet.

Pada platform Youtube juga terdapat banyak sekali materi yang berkaitan dengan pidato, sehingga siswa maupun guru dapat mengaksesnya. Youtube juga dapat menjadi sarana pengumpulan tugas, siswa diminta untuk mengunggah video pada platform ini, kemudian melalui tautan yang diberikan, guru dapat melakukan penilaian, khususnya pada praktik berpidato.

\section{Roda Putar}

Roda putar atau spinner merupakan sebuah lingkaran yang nantinya akan berisi beberapa pilihan yang bisa diatur penggunanya. Roda putar ini telah tersedia secara daring, sehingga pengguna tidak memerlukan aplikasi untuk menggunakannya. Berikut adalah contoh roda putar yang dapat kita akses di https://pickerwheel.com/ : 


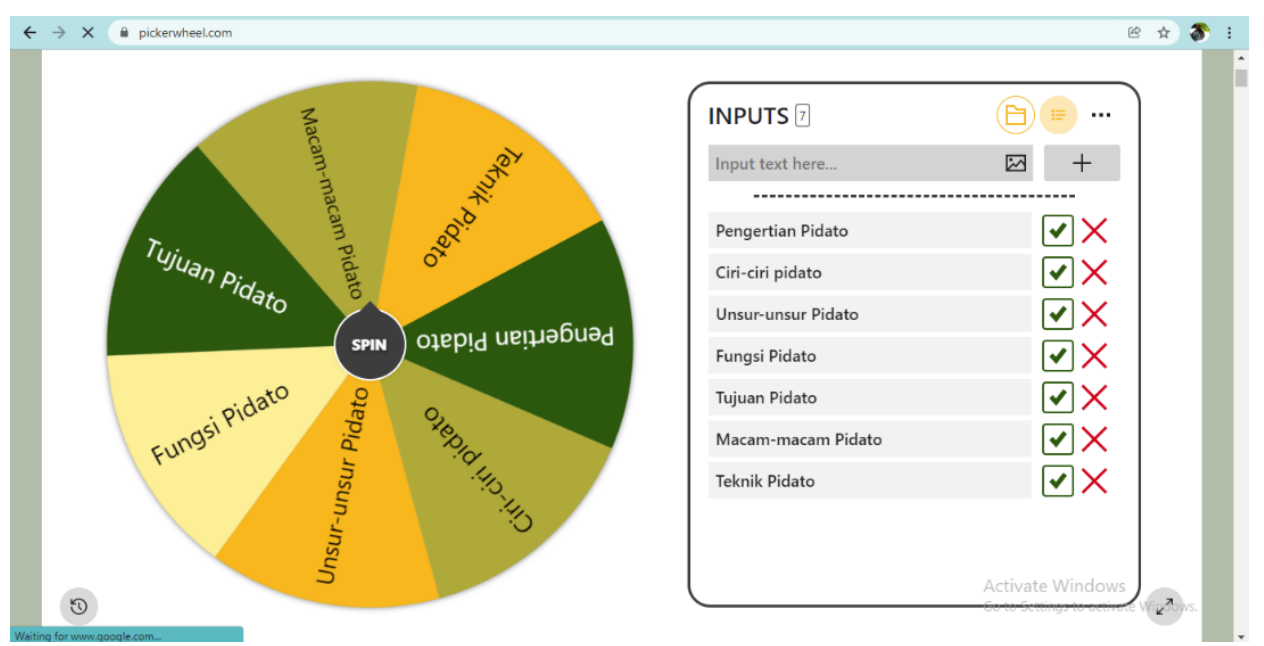

Pada bagian input text here, pengguna dapat menambahkan pilihan pada roda putar, setelah itu klik tanda tambah. Lakukan hal yang sama sebanyak berapa pilihan yang akan diputar. Setelah pilihan telah selesai ditambahkan seluruhnya, klik spin dan nantinya akan muncul pilihan hasil dari pemutaran, seperti gambar berikut:

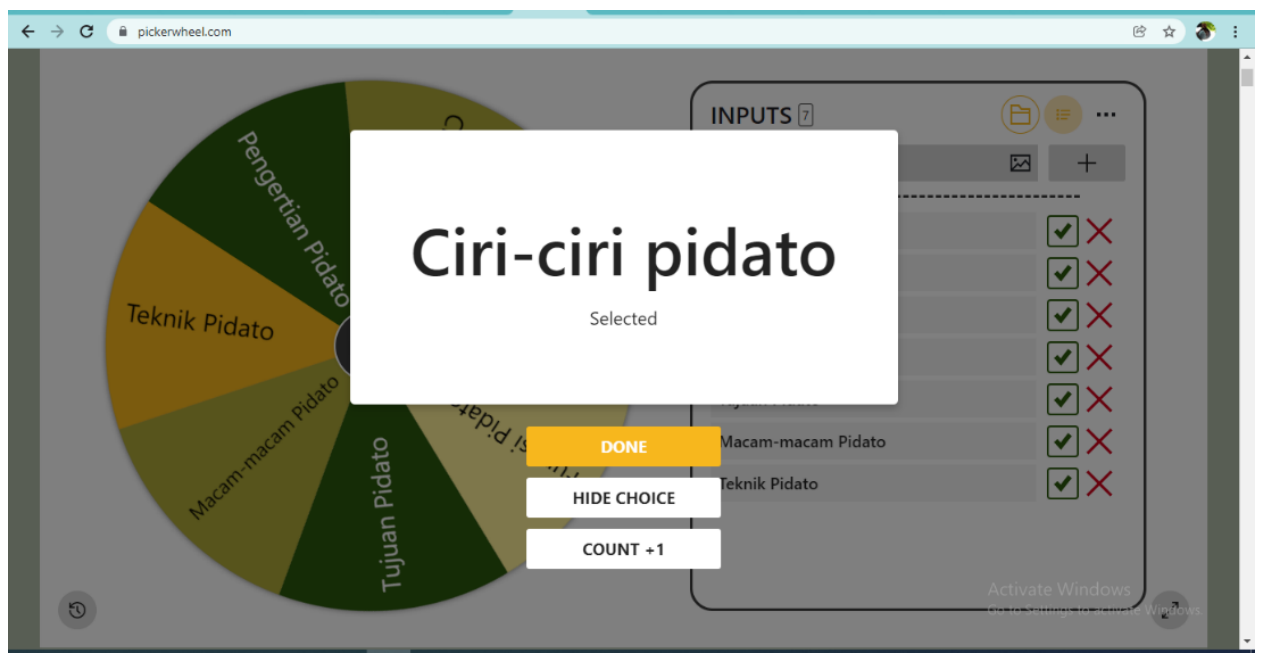

Penggunaan roda putar ini dapat menarik minat siswa dan antusias untuk menantikan hasilnya. Penggunaan ini dapat dimodifikasi sesuai keperluan. Saat ini, sudah begitu banyak situs ataupun aplikasi yang menyediakan roda putar sehingga kita tidak perlu bersusah payah mencarinya. 


\section{Quizizz}

Quizizz sendiri, merupakan aplikasi permainan pendidikan yang sifatnya naratif dan fleksibel, selain bisa dimanfaatkan sebagai sarana menyampaikan materi, Quizizz juga bisa digunakan, sebagai media evaluasi pembelajaran yang menarik dan menyenangkan (Salsabila, Habiba, Amanah, Istiqomah, \& Difany, 2020:165). Pada quizizz pengguna dapat membuat pertanyaan dengan 4 jawaban, pertanyaan ini dapat ditambahkan latar belakang berupa sebuah gambar yang membuat tampilannya semakin menarik. Quizizz dapat dimainkan kapan dan dimana saja oleh siswa tetapi tidak boleh melebih waktu yang ditentukan. Tiap soal dapat diatur waktu menjawabnya, dan soal dapat diacak sehingga memungkinkan siswa tidak dapat bertanya kepada temannya atau melihat jawaban dari sumber lain. Pada akhir kuis, siswa dapat langsung mengetahui poinnya dan berapa soal yang mereka jawab benar atau salah. Quizizz juga memudahkan guru karena terdapat fitur peringkat otomatis dan dapat diunduh berupa berkas excel.

Quizizz dapat diunduh melalui Google Play Store atau dapat diakses tanpa aplikasi melalui tautan http://quizizz.com/. Tampilan awalnya setelah pendaftaran adalah sebagai berikut:

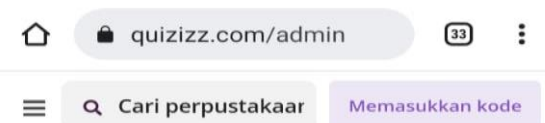

Q Apa yang akan kamu ajarkan hari ini?

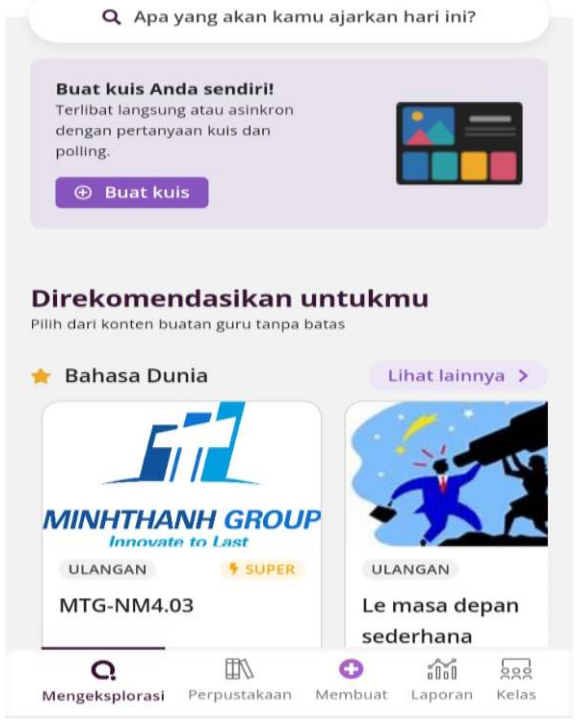


Bagi guru, dapat dibuat soal dan nantinya akan muncul kode yang dapat dibagikan kepada siswa agar siswa dapat mengakses soal tersebut. Aplikasi ini juga memudahkan guru untuk mengetahui tingakt pemahaman siswa terhadap materi pelajaran yang diajarkan.

\section{Tindakan Solutif}

Berbagai macam inovasi yang ditemukan, tentu akan mengalami kendala dalam pelaksanaannya. Tapi hal tersebut tidak boleh menyurutkan niat untuk mempelajari teknologi baru agar tetap bisa menyesuaikan dengan perkembangan zaman, dan terpenuhinya hak peserta didik untuk mendapatkan pendidikan. Beberapa gangguan yang akan dihadapi dapat berupa pemahaman untuk fitur-fitur yang disediakan. Tentulah semua orang tidak langsung paham terhadap fitur yang ada pada sebuah aplikasi, mereka haruslah mencari tahu terlebih dahulu bagaimana menggunakannya. Pengetahuan ini dapat dilakukan secara otodidak, yaitu mengotak-atik sendiri tentang fitur-fitur yang ada. Kemudian dapat pula menggunakan bantuan situs-situs yang menyediakan bacaan mengenai aplikasi yang ingin dipelajari, atau melihat video penggunaanya melalui platform Youtube.

Kendala selanjutnya yang akan ditemukan dapat pula berupa tidak adanya perangkat pendukung pembelajaran daring seperti telepon genggam yang dapat mengakses internet. Kendala ini akan ditemui oleh guru atau peserta didik, sehingga tindakan yang harus dilakukan adalah memberdayakan warung internet (warnet) yang tersedia, atau meminjam telepon genggam/pintar kepada orang yang memilikinya, hal ini demi terlaksananya pembelajaran. Kemudian untuk memperkaya wawasan serta referensi peserta didik maupun guru, alangkah lebih baiknya disediakan dalam folder berupa kumpulan beberapa materi dan video yang berkenaan dengan materi yang sedang diajarkan kepada peserta didik. Apabila terkendala pada jumlah kapasitas kartu memori, dapat menggunakan google drive yang dapat diakses oleh seluruh peserta didik. Google drive memberi keringanan dengan menyediakan 15 GB penyimpanan yang dapat disimpan melalui google, sehingga memudahkan untuk menyimpan berkas. 
Selalu memberi stimulus kepada peserta didik, dan menerapkan inovasiinovasi saat kelas berlangsung dapat meningkatkan perhatian peserta didik dalam memperhatikan materi pembelajaran yang sedang diajarkan. Guru juga dapat meningkatkan kemampuan diri dengan mengikuti seminar-seminar kependidikan sehingga nantinya dapat berpengaruh dalam pekerjaannya dan menjadi lebih baik dari sebelumnya.

\section{Simpulan}

Pada masa pandemi guru dituntut untuk menjadi lebih kreatif untuk meningkatkan minat belajar siswa, sehingga siswa akan asyik saat mengikuti pelajaran yang diajarkan. Terlebih ketika materi yang sifatnya langsung dialihkan menjadi tidak langsung seperti pidato tentu memerlukan beberapa cara dan strategi maupun inovasi agar materi tersebut tetap terlaksana seseuai dengan tujuan. Belajar pidato jadi lebih menarik karena aplikasi dan situs yang sudah tersedia di internet.

Aplikasi-aplikasi yang disediakan di internet telah mempermudah guru dan siswa untuk melakukan proses belajar mengajar. Tugas kita adalah mempelajarinya, mengolahnya dan menciptakan pembelajaran yang menyenangkan agar dapat diikuti oleh semuanya. Aplikasi ini juga dapat digunakan pada materi pelajaran lainnya. Inovasi yang muncul juga dapat merangsang guru dan siswa untuk berpikir kreatif, sehingga mampu menciptakan atau membuat model baru yang lebih menarik lagi. 


\section{Referensi}

Aditia, S. (2021). Inovasi Pembelajaran Berbasis Aplikasi Mobile Pada Masa Pandemi Covid 19.

Ayu, M., Sari, F. M., \& Muhaqiqin, M. (2021). Pelatihan Guru dalam Penggunaan Website Grammar Sebagai Media Pembelajaran selama Pandemi. AlMu'awanah: Jurnal Pengabdian kepada Masyarakat, 2(1), 49-55.

Faizah, H. Pengembangan Media Berbasis CD Interaktif Pada Mata Kuliah Penelitian Tindakan Kelas. Jurnal Bahas, 10(1), 31-37.

Huriah, H. (2021). Upaya Meningkatkan Prestasi Belajar Bahasa Indonesia Materi Pidato Atau Presentasi Melalui Penerapan Model Examples Nonexamples Peserta didik Kelas VI SDN 4 Dasan Geres Pelajaran 2018/2019. MEDIA BINA ILMIAH, 16(3), 6485-6494.

Mustafa, M. N., Hermandra, Z., \& Zulhafizh, Z. (2019). Teachers' Strategies to Design Media to Implement Communicative Leaning in Public Schools. Journal of Educational Sciences, 3(1), 13-24.

Rahma, A. A., \& Arista, H. (2021). Analisis Penerapan Google Classroom Untuk Meningkatkan Mutu Pembelajaran Online di Masa Pandemi Covid19. Pedagogy: Jurnal Ilmiah Ilmu Pendidikan, 8(1), 88-95.

Salsabila, U. H., Habiba, I. S., Amanah, I. L., Istiqomah, N. A., \& Difany, S. (2020). Pemanfaatan Aplikasi Quizizz Sebagai Media Pembelajaran Ditengah Pandemi Pada Siswa SMA. Jurnal Ilmiah Ilmu Terapan Universitas Jambi| JIITUJ|, 4(2), 163-173.

Zulhafizh \& Permatasari, S. (2020). Developing Quality of Learning in the Pandemic Covid-19 Through Creative and Critical Thinking Attitudes. JURNAL PAJAR (Pendidikan dan Pengajaran), 4(5), 937-949. 


\section{*Data Penulis}

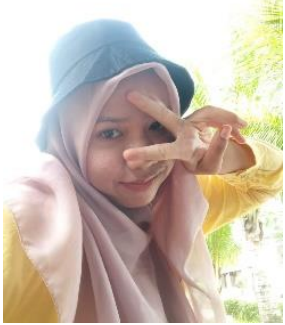

Sari Oktafiani, lahir di Duri, 11 Oktober 2000. Merupakan anak terakhir dari lima bersaudara. Tahun 2019 menyelesaikan pendidikannya di SMA Negeri 1 Mandau. Pada tahun akademik 2019-2020, Ia melanjutkan studi pada strata satu Jurusan Pendidikan Bahasa dan Seni di Program Studi Pendidikan Bahasa dan Sastra Indonesia FKIP Universitas Riau melalui jalur SNMPTN (Seleksi Nasional Masuk Perguruan Tinggi Negeri). Beberapa kali menjuarai lomba puisi, dan menjadi panitia pada acara nasional seperti Bulan Bahasa dan Praktikum Sastra yang ditaja oleh Himpunan Mahasiswa Pendidikan Bahasa dan Sastra Indonesia Universitas Riau.

Kontak:

Hp/WA : 085363470039

Email : sarioktafiani39@gmail.com 